\title{
Approaches to Skills Mismatch in the Labour Market: A Literature Review ${ }^{1}$
}

\section{Guillem Sala}

Universitat Autònoma de Barcelona. Grup de Recerca sobre Educació i Treball (GRET) ${ }^{2}$ University of Oxford. Centre on Skills, Knowledge and Organisational Performance (SKOPE) guillem.sala@uab.cat

\begin{abstract}
Skills mismatch in the labour market describes the fact that levels or types of skills of individuals are inadequate in view of particular job requirements. There exists no accepted unified theory of skills mismatch. The overeducation literature, inspired by several classical theoretical frameworks (human capital theory, job competition, and assignment models), attempts to define and measure the incidence of the phenomenon, but often understates the heterogeneity of both jobs and manpower. Some authors have tried to make up for this deficit by focusing on specific groups or individual abilities. By contrast, a competence approach places the observed no-causality relationship between training and occupation at the centre of its analysis, rather than considering it as a market imperfection. By doing so, it provides an alternative way of conceptualising skills mismatch, and promisingly challenges the normative assumptions and current applications of the classical frameworks.
\end{abstract}

Key words: labour market; mismatch; skills; competences; overeducation.

Resumen. Análisis del desajuste de competencias en el mercado laboral: un estado de la cuestión

El desajuste de competencias en el mercado de trabajo describe el hecho de que el nivel y/o el tipo de formación de los individuos no se adecuan a aquellos que requieren sus puestos de trabajo. A pesar de que la literatura de la sobreeducación, inspirada en los marcos teóricos clásicos (básicamente la teoría del capital humano), intenta definir y medir la incidencia del desajuste, no existe una teoría unificada sobre dicho fenómeno. Sin embargo, estos análisis omiten a menudo la heterogeneidad, tanto de los puestos de trabajo como de la

1. This paper results out of research cooperation between SKOPE (University of Oxford and University of Warwick), GRET (Universitat Autònoma de Barcelona), LIRHE (CNRSUniversité de Toulouse 1) and HIS (Institute for Advanced Studies, Vienna). I thank the Agència de Gestió d'Ajuts Universitaris i de Recerca (Generalitat de Catalunya) and the Department of Educational Studies of the University of Oxford for support.

2. GRET (Research Group for Education and Work) is a research group in the Department of Sociology of the Universitat Autònoma de Barcelona, founded in 1987. 
propia mano de obra. Algunos autores se han enfrentado a este vacío desde distintas perspectivas (grupos específicos, habilidades individuales, etc.). Más allá, un enfoque basado en competencias sitúa la relación no causal observada entre formación y empleo en el centro de su análisis, más que considerarla como una imperfección del mercado. Así, ofrece una vía alternativa para conceptualizar el desajuste de competencias y cuestiona los supuestos normativos que subyacen en las perspectivas clásicas.

Palabras clave: mercado laboral; competencias; desajuste; sobreeducación.

\section{Summary}

Introduction

1. Theoretical Frameworks

2. Methodological Approaches

3. Consistency of the Observed Facts with Theoretical Frameworks
4. Taking Heterogeneity into Account

5. The Competence Approach

6. Concluding remarks

Acronyms

Bibliographic references

\section{Introduction}

Skills mismatch in the labour market (SMLM) describes the fact that levels or kinds of skills of individuals are inadequate in view of particular job requirements. Through his pioneering use of the notion of overeducation, Richard Freeman brought this subject to the attention of researchers (Freeman, 1976). ${ }^{3}$ This field of study has grown since the late 1980s as sociologists and economists attempt to evaluate the consequences of educational expansion in the labour market.

At the macroeconomic level, a potential waste of production arises when some proportion of worker skills used productively. There may also exist an underutilisation of equipment. At the level of the firm, there exists some evidence to suggest that excess skills lowers productivity.

Nevertheless, not all researchers believe that overeducation is a permanent phenomenon, or that it is associated with high costs. Many economists are reticent to accept this notion, raising questions concerning the validity of the assumptions and forecasting associated with the dominant (neoclassical) conception of the labour market. A significant portion of the debate within the literature focuses on the extent to which the existence of SMLM represents a genuine challenge to human capital theory (HCT) or instead constitutes a statistical artefact generated by either inadequate measurement techniques or a lack of sufficient controls in the standard wage equation framework.

3. Despite the huge influence of Freeman's work, note that he employs "overeducation" only as a descriptive term to characterise the collapse of the market for college workers during the 1970s, based on the observed decline in college earnings. Freeman's work does not explicitly consider the level of general mismatch that exists between education levels and job requirements. 
This paper examines the skills mismatch literature and provides an overview of the theoretical and methodological debates that surround the SMLM analysis. The paper is structured as follows. Section 1 provides a summary of the main theoretical frameworks within which researchers have attempted to explain skills mismatch in the labour market. Section 2 looks at the main methodological approaches to this phenomenon: manpower planning and overeducation measurement. Section 3 evaluates the theoretical perspectives with respect to the empirical evidence reported in the literature. Section 4 focuses on taking the heterogeneity of workers' skills into account. Section 5 presents the competence approach as an attempt to surpass the normative assumptions of the dominant neoclassical models. Finally, section 6 offers a number of concluding remarks.

\section{Theoretical Frameworks}

There exists no accepted unified theory of SMLM, although some authors have attempted to conceptualise and explain the problem within the framework of semi-formal economic models (Freeman 1976; McMillen et al., 1999). Nevertheless, a large part of the literature on overeducation considers the phenomenon within the context of existing views of the labour market, and quite a few studies have conducted empirically tests to ascertain which theoretical perspective is most consistent with the observed facts (Duncan and Hoffman, 1981; Rumberger, 1987; Hartog and Oosterbrook, 1988; Groot, 1996; Sloane et al., 1999; Battu et al., 2000; Dolton and Vignoles, 2000). Sloane (2003) even argues that the major contribution of the overeducation literature has been to widen the debate on the importance of job characteristics in determining wages, thus broadening the human capital framework. This section offers a broad overview of the three main labour market perspectives, and assesses the consistency of each view given the presence of overeducation in the labour market.

\subsection{Human Capital Theory}

The dominant explanation of the distribution of earnings in developed economies arises from Becker's (1964) monograph Human Capital. According to Heckman et al. (2003), Mincer's earnings model (1974) also represents a seminal work in the field of the economics of education and work, providing an empirical framework to assess and measure HCT predictions.

Becker (1964) assumes that workers will always be paid their marginal product. Thus, firms will adapt their production processes to reflect changes in the relative supply of labour. Wages match the individual worker's marginal product, which is determined by the level of human capital acquired through initial formal training and on-the-job training. ${ }^{4}$ By assuming so, HCT affirms that employers will fully utilise the skills of their employees. Both overeduca-

4. Becker holds that individual workers are substitutable. 
tion (worker underutilisation) and wage rates below the marginal product are inconsistent with this approach to the labour market.

Nevertheless, many economists continue to argue that HCT remains fully consistent with the empirical evidence regarding overeducation. They state that it is possible that workers will be overeducated in the short run, while they are looking for a more appropriate job or while firms adapt their production processes to fully utilise the individual's human capital. HCT is therefore consistent with the existence of short-term mismatches.

Mincer (1974) develops an earnings regression based on years of schooling, in which less formal measures of human capital, such as on-the-job training, are ignored. Individuals with more formal schooling may be compensating for a lack of work-related human capital, and the apparent lower earnings of these overeducated individuals may be due to an omitted variables problem (e.g., lack of control for less formal forms of human capital accumulation). Mincer's framework is presented as another explanation for overeducation consistent with the neoclassical view (McGuinness, 2006).

The HCT approach offers a third explanation for overeducation by considering the possibility that overeducated workers have less abilities compared with workers whose jobs are appropriately matched to their qualifications. In this explanation, lower wages are a reflection of lower productivity. If evidence of such skill differences is found, the bias in the estimated wage effect of overeducation would be picked up by the empirical framework.

Whilst some authors suggest that HCT is inconsistent with the observed overeducation (Dolton and Vignoles, 2000), others argue this framework remains valid because evidence of overeducation as a short-term phenomenon or the existence of worker skill heterogeneity may explain those apparent inconsistencies.

\subsection{Job Competition Model}

Several economists question the ease with which firms are able to adjust their production techniques to facilitate changing factor input prices (Duncan and Hoffman, 1981; Hartog and Oosterbeek, 1988), especially where firms employ team work technology that brings together groups of heterogeneous workers. In addition, institutional arrangements, such as national pay agreements, may be far more rigid than suggested by HCT. If firms cannot adapt without delay, or cannot adapt at all, individuals productivity - and hence their earnings will also depend on their jobs characteristics.

The job competition model suggests that job characteristics may be the only factor determining earnings. Based on Lester C. Thurow's Generating Inequality (1975), the model has attracted considerable attention within the overeducation literature. Thurow's model characterises a labour market market as competition for job opportunities based on individuals' relative training costs, in contrast to labour market competition based on the wages individuals are willing to accept given their human capital. 
This model emphasises the importance of a person's relative position compared to other workers competing for jobs. Thurow (1975) postulates that when an individual observes his neighbour participating in education, he would be less likely to participate in education: in the HCT framework supply would be higher and the return less. However, under the Job Competition Model, the same individual would now be more likely to participate, for education becomes a "defensive necessity" to protect one's place in the job queue. The larger the numbers of educated persons in the economy, the more imperative it becomes for an individual to invest in education.

The Job Competition Model provides a clear explanation for educational overinvestment, and consequently for overeducation. In many ways, the model is very similar to the signalling framework in that individual investments are motivated by the goal of preserving one's position, although in Spence's (1973) model the amount of education an individual will invest in is limited by the balance between earnings and the cost of education. While it is difficult to determine when a ceiling of educational participation is reached, the job competition framework nevertheless provides a theoretical framework that is entirely consistent with the existence of overeducation. Thurow's model implies that wages will be wholly dependent upon required education, and also that the returns to education in excess of that required by the job (surplus education) will be zero.

\subsection{Assignment Models}

The assignment literature offers a middle ground between the two extreme perspectives outlined previously. Despite some differences amongst them, all assignment models specify jobs or sectors available to workers, the relevant differences between workers, the technology relating job and worker characteristics to output, and the mechanisms that assign workers to jobs. Within this framework, the earnings function no longer constitutes a directly observable relationship, but instead represents the equilibrium outcome to the solution of the assignment problem. Sattinger (1993) points out that relative wages have changed over time with earnings becoming more unequal. $\mathrm{He}$ argues that these changes are hard to explain in the standard neoclassical framework in which productivity and earnings are exclusively linked to education and experience, and thus independent of the availability and quality of jobs in the economy.

The general predictions of assignment models concerning the allocation of workers to jobs, and their subsequent earnings, are more important in the context of overeducation. Assignment models differ significantly from the job competition perspective by stressing that choice of job or sector creates an intermediate step between an individuals' characteristics and their earnings. The job allocation process is not merely a lottery; instead, income maximisation motivates workers to choose particular jobs over others. Higher wages for workers with particular characteristics therefore play an allocative role in the economy rather than being mere rewards for the possession of characteristics. 
The distribution of workers is not random but based on their own choices and aimed at maximising income or utility. The central prediction from the assignment literature is that an adequate explanation of changes in the distribution of earnings implies considering both individual characteristics and job characteristics. Thus, overeducation is entirely consistent with an assignment interpretation by suggesting that marginal product and earnings will depend on both the individual and the job. In addition, these models imply that there is no reason to expect wage rates either to be wholly related to acquired schooling or other individual attributes (HCT), or to be wholly related to the nature of the job (Job Competition Model).

\section{Methodological Approaches}

\subsection{Manpower Planning}

One of the most influential applications of the adequationist approaches to SMLM (mainly HCT) is provided by manpower or employment techniques. Employment planning is concerned with macro policy instruments creating employment and is mainly carried out in Ministries of Planning or Economy in developing countries. Concerns about the specific amount of entrants to the labour market, the impact of investments on labour productivity and employment levels, or the effect of an increase in the minimum wage on employers' desire to hire labour feature at the core of this application.

According to Youdi and Hinchliffe (1985), the dominant model of manpower planning is known as the Manpower Requirements Approach (MRA), first appearing in the OECD's Mediterranean Regional Project in the early 1960s. The three major steps in MRA manpower forecasting are: (a) projecting the supply of educated manpower; (b) projecting the demand of educated manpower; and (c) balancing supply and demand.

An entirely different approach from MRA is the Rate of Return (RoR) approach. RoR calculates the net returns of educational expenditure, measured as the increase in net income that an individual will be able to command throughout his life compared with the income he would have received if he had not reached a given educational level (ILO, 1984). The present value of the flow of future net income is calculated on the basis of this definition for each educational programme. Programmes that show positive returns should be promoted, while those showing zero or negative net present value should be reduced or even abandoned.

In addition these two major approaches to manpower planning, there exists a vast range of manpower planning techniques and labour market information signalling and assessment strategies outside of the scope of this analysis.

\subsection{Overeducation Measurement}

At its core, manpower planning faces the problem of mismatch between labour supply and demand, or overeducation. In academic circles, overeducation 
studies have largely replaced the quest for manpower planning techniques. According to Hartog (2000), Sloane (2003) and McGuinness (2006), three main alternative measures have been used to estimate the degree of overeducation: job analysis, worker self-assessment, and realised matches.

\section{a) Job Analysis}

Job Analysis (JA) is the systematic evaluation by professional job analysts of the required level of education for job titles, through an occupational classification of the level of qualifications required to perform a particular job. While often referred to as an objective measure, Sloane (2003) maintains JA is better regarded as an objective measure based on subjective values or, as pointed out in Béduwé et al. (2005), as a normative definition of matching performance.

Systematic JA has the explicit goal of objectivity, clear definitions and detailed measurement instructions..$^{5}$ JA can even indicate the scope for substitution of different levels and types of educations, starting from the technology of the job and the type of tasks to be performed.

However, the careful and systematic work required for JA may be too expensive to carry out on a large scale. Subsequent editions of the DOT Handbook, published at wide time intervals, in many cases simply copy earlier analyses and thus only a small share of the analyses is new (Hartog, 2000). This makes an assessment of changes in the job structure on the basis of information from subsequent editions unreliable (Cain and Treiman, 1981). Furthermore, translating the job requirements into a single schooling variable may introduce substantial errors. Glebbeek (1993) has demonstrated for the Netherlands that assigning job level codes to survey responses on type of work entails a large measurement error (a low correlation of repeated assignment). Verdugo and Verdugo (1992) note that, according to the DOT Handbook, only a single job analyst visits the job site and discusses requirements with the employer. They too doubt both the reliability and validity of the measure.

\section{b) Worker Self-assessment}

In the Worker Self-assessment Method (WA), the worker specifies the education required for the job. This method may involve a direct and explicit specification of the type of schooling required, or it may take an indirect form by stating whether a higher or a lower level (or a different type) of education is needed, using the worker's actual education as a benchmark. There may exist slight variations in the specification of type of schooling. For instance, in the American PSID data Sicherman (1991) uses responses to the question: "How much formal education is required to get a job like yours?" Alba-Ramirez (1993), on the other hand, focus on the question: "What kind of education does a person need in order to perform your job?"

5. See, for example, the discussion in the Dictionary of Occupational Titles (DOT) (US Department of Labor, 1965). 
Worker self-assessment draws on all local, up-to-date information. In principle, the assessment deals with the respondent's particular job, not with aggregate types. However, Sloane (2003) beliefs WA lacks rigorous instructions: individuals easily overstate the requirements of their job to inflate the status of their position, or they simply reproduce actual hiring standards. This causes problems if actual schooling levels in the labour force increase over time, and employers adjust hiring standards but the jobs themselves have not changed. Sicherman (1991) argues that such a bias does not explain the overeducation observed in the US. He compares the schooling of overeducated workers in 1976-1978 with the average education of their age-occupation cohort in 1970, and finds that it is higher. A similar comparison for undereducated workers finds that they are less educated than their earlier counterparts: the effects are therefore not caused by a general rise in education level (Sicherman, 1991).

Both JA and WA measures refer to the level of education rather than to the type of education. Thus, a worker may still be mismatched in cases where the level of education is appropriate, but its type is inappropriate. There is also disagreement over whether JA or WA is more accurate in practice for defining the true educational requirements of jobs. Van der Velden and van Smoorenburg (1997) favour WA because the job evaluation method systematically overestimates the level of overeducation, while Hartog and Oosterbeek (1998) suggest WA may lead to an upward bias.

\section{c) Realised Matches}

A third empirical method for measuring overeducation is based on analysing realised matches (RM). In this method, required education is derived from the customary (mean or mode) education level attained by workers in the respondent's job or occupation. Mismatching is said to occur when the level of education is more than one standard deviation above or below the mean in a given occupation.

Hartog (2000) states that using RM fails to uncover the technological requirements of a job. RM measures the allocation of the actual assignment practice as determined by hiring standards and labour market conditions. This allocation is endogenous in the same way as the quantity traded is endogenous in a standard textbook market model. This implies RM information should be interpreted as the market result in an assignment model, not as a shift indicator of the demand curve. Heeding Hartog's (2000) warning, realised matches should be interpreted differently from the other two measures, reminding us of demand curve location parameters.

Two different measures can be derived from the RM empirical method. The first measure defines required schooling as a one standard-deviation range around the mean level of schooling in an occupation (Verdugo and Verdugo, 1989). Workers are considered to be adequately educated if their actual education falls within this range, overeducated if their actual education is greater than one standard deviation above the mean for the specific occupation, and 
undereducated if their actual education is more than one standard deviation below the mean education. The main criticism of this measure is its subjective nature due to the arbitrary choice of one standard deviation.

This empirical method cannot be directly compared with the other two measures as it ignores minor differences between actual and mean education. This difference is more striking when the question asked under job analysis and worker self-assessment requires a simple yes or no response. RM also implies symmetry between overeducation and undereducation, which is rarely found in practice and is therefore likely to bias estimates. Sloane (2003) even states that it is doubtful whether we should refer to overeducation or undereducation in this context.

Comparing the merits of the three measures, Sloane (2003) and Hartog (2000) consider JA to be conceptually superior. However, they warn that its actual measurement does not often meet the highest standard of accuracy. JA measures are generally only available for specific years: because of the cost of implementation, up-to-date JA measurements are usually not available, and in practice WA will often be the best available measure. RM comprises observations of the equilibrium realised by the interplay of supply and demand; it is therefore an inadequate measure of the demand side.

\section{Consistency of the Observed Facts with Theoretical Frameworks}

This section evaluates the empirical evidence in light of the different theoretical perspectives outlined previously. McGuinness (2006) holds that most of the evidence, emanating from studies estimating wage equations based on the decomposition of educational years acquired, have found that the returns to surplus education are positive and significant, but nevertheless tend to be lower than the returns to required education. Most researchers have interpreted this as evidence against HCT, which implies equal returns to surplus and required education. However, Rumberger (1987) found no reward to surplus schooling in certain occupations, suggesting that the job competition model may adequately explain behaviour within particular job markets - a point consistent with Thurow's (1975) initial analysis.

Hartog and Oosterbeek (1988) reported that for Dutch females, the assignment specification, though superior to the job competition model, was lower to the specification derived from HCT, which they rationalize within the context of differences in labour supply behaviour. They state that both for participation and hours worked, female labour supply has substantially higher wage elasticities than male supply. This explains why females are paid the returns to their actual education even in jobs for which they are overeducated. The model also suggests that elasticities of female labour supply fall with education level, thus allowing for full wage correction in jobs where females are undereducated; nevertheless, as the authors point out, these results require further research (Hartog and Oosterbeek, 1988). However, this finding is unlikely to be unique to the Dutch labour market: Vahey (2000) reported no lower return to surplus 
education for overeducated Canadian females, despite observing lower returns for some overeducated Canadian males.

A number of authors have adopted different approaches to assess the adequacy of the different frameworks. Battu et al. (2000) examined the HCT prediction that firms upgrade the tasks they give to their overeducated workers by testing for the hypothesis that graduates' jobs converge over time, rendering overeducation a temporary phenomenon. However, they found as much divergence and convergence in the nature of the work for the overeducated compared with those who are in matched employment. In other words, they found no evidence to suggest that overeducated graduates have been able to upgrade their jobs, suggesting again that overeducation may be a long-term problem. Finally, McGuinness (2003) rejected the hypothesis that coefficients on both human capital and job description variables were jointly zero within a wage equation model, demonstrating in support of the assignment model that both human capital and job characteristics are important factors in determining wage rates.

Groot (1996) found that younger, higher educated cohorts have relatively less access to high-qualified jobs than older workers. This may simply reflect the fact that these older (more experienced) workers entered the labour market during a period when there was a higher availability of high-skilled jobs. This suggests the explanatory power of existing studies examining the link between overeducation and informal human capital accumulation is weakened by a failure to account for cohort influences.

Examining the hypothesis that overeducated workers are less able than their well-matched counterparts, Groot (1996) reports that the negative wage effects of overeducation (for men) increase over time. This finding supports the view that employers tend to pay workers less as they find out more about the productive abilities of overeducated workers, suggesting that overeducated men are unproductive. Sloane et al. (1999) also claim that overeducated workers are less able, citing evidence that they are less likely to be promoted. Green et al. (1999) reported evidence that the overeducated tended to have lower mathematical abilities, arguing that the overeducated are likely to possess less innate ability. However, they also found that the overeducated were more likely to have better prose and documentation skills, which suggests that the differences between the adequately matched and the overeducated are more readily related to variations in the nature of the education undertaken. For instance, students electing to take more Arts and Social Science A levels, as opposed to more vocational itineraries, may be exposing themselves to a higher likelihood of being overeducated.

However, there also exists evidence to suggest that overeducated workers are more able than their undereducated counterparts. For instance, Mendes de Oliveria et al. (2000) found that employers tend to value and prize overeducation and penalize undereducation. With prolonged tenure, overeducated workers were granted an ascending path of relative earnings, while undereducated workers saw their relative position eroded. 
The extent to which overeducation is consistent with models of occupational mobility has also been examined; as with the previous two propositions, the evidence is mixed. Mobility frameworks argue that overeducation constitutes a transitory phenomenon that will gradually disappear as workers improve their labour market position. In support of this, Sicherman (1991) reported that overeducated workers have higher rates of firm and occupational mobility, and they are more likely to move to a higher occupation.

Alba-Ramirez (1993) found that the proportion of overeducated workers falls with age, hinting at a particular pattern in the upgrading process of overeducated workers throughout their working lives. Alba-Ramirez also reported that overeducated workers have a high job turnover rate, which points at improved matching over time. However, the finding that mobility does not necessarily equate with an improved labour market position was also reported by Sloane et al. (1999), whilst McGuinness (2003) concluded that a large part of the observed mobility consists of workers moving from one overeducated position to another. In addition, Dolton and Siles (2001) conclude that being overeducated in first employment tends to permanently restrict graduates to low-level occupations.

Finally, more recent research has indicated that the permanency of the overeducation effect is related to the nature of the labour market. For instance, Groeneveld and Hartog (2004) reported that career development in the internal labour market is substantially impeded as a result of overeducation.

\section{Taking Heterogeneity into Account}

The dominant methods of measuring overeducation consider the educational variable only in terms of level of education, not in terms of type of education. A number of authors have attempted to accommodate this factor by taking into account the heterogeneity of workers presenting the same level of education. The construction of a combined educational variable (such as the "level-speciality" variable in Béduwé et al., 2005) is mostly neglected in the SMLM literature. The main options disaggregating the level of education in further nuances are "specific group" (the discrimination of particular labour market groups, such as women, ethnic minorities or the disabled) and, predominantly, individualised skills.

\subsection{Specific groups}

We have good reason to expect that groups suffering from discrimination will find it more difficult to compete in the labour market, and overeducation may be one consequence of such discrimination.

This view is supported by the fact that young workers are particularly vulnerable as new entrants into the labour market, and the finding that overeducation is linked to lack of work experience. Dekker et al. (2002) find that in their Dutch sample the overeducated proportion falls from $41.7 \%$ for the $15-19$ age group to $27 \%$ for the $30-44$ age group and $18.0 \%$ for the $49-64$ age group. 
We have equally good reason to expect married women to be particularly vulnerable to overeducation (see the theory of differential overqualification in Frank, 1978). Given fixed costs of employment and a higher turnover rate for women than for men, employers may require a higher ability from women relative to men at the hiring stage of a given job. Using Dutch data to test this model, Renes and Ridder (1995) find that women on average are required to have almost six months more work experience than men to be hired for the same job, which makes them overqualified on a broad view of human capital. In their meta-analysis, Groot and Maassen van den Brink (2000) suggest that overeducation is more frequent among female workers than among male workers, while the opposite holds true for undereducation. However, the likelihood of overeducation is not very different for men and for women. In their study of young French workers aged 18-29, Forgeout and Gautie (1997) found that $24 \%$ of women were overeducated in comparison with $18 \%$ of men. By contrast, using a mean index, Bauer (2002) found that $15.6 \%$ of females in Germany were undereducated compared with $10.4 \%$ of males. These differences may vary across different countries and different groups.

Ethnic minorities too may be more prone to overeducation compared with the ethnic majority if hiring discrimination exists. While scant analysis of the relative position of ethnic minorities exists, Duncan and Hoffman (1981) nevertheless found that $49 \%$ of black males were overeducated compared with $42 \%$ of the US male workforce as a whole. Similarly, Alpin et al. (1998) found that $30 \%$ of non-white graduates in the UK were overeducated compared with $27 \%$ of white graduates. However, it is important to distinguish between native-born and foreign-born ethnic minorities as well as between different ethnic groups (Battu and Sloane, 2002). Foreign qualifications, being UK born and language fluency all raise the likelihood of being both overeducated and undereducated.

\subsection{Individual skills}

The frequent omission of any measure of ability in studies of overeducation prevents us from knowing whether the worker is overeducated because he has low ability given a particularlevel of education. It is usually assumed throughout the literature that more able individuals stay longer in school. This results in an upward bias in the estimated return to years of schooling (or to qualifications dummies) and, therefore, in an overestimation of the rate of return to schooling. Hartog (2001) interprets the literature as suggesting that the schooling coefficient would be reduced by no more than a third if ability variables such as IQ test scores were included, with a main tendency perhaps in the range of 10 to $15 \% .^{6}$.

6. A confounding factor in the context of the overeducation literature is the evidence of interlocking heterogeneities. This means the relevance of factors such as abilities and personalities varies according to type of occupation. 
At least four procedures have been used to correct for this problem: IQ tests, data from identical twins or siblings, panel data treating ability as a constant over time, and an instrumental variable technique that purges schooling of any association with ability. Without such a correction, the overeducation literature implicitly assumes not only that ability bias is not a problem, but also that there is no ability variation within a particular education qualification level.

Battu et al. (2000) are a rare example of authors who compare the results of different measures of overeducation applied to the same data set. Using data from two cohorts of UK graduates, they find that the scale of overeducation varies with measurement techniques but only generates weak correlations between their three measures: 1) answers to a yes/no question about whether a degree was a job requirement in current employment; 2) a measure of whether a modal worker was a non-graduate; and 3) answers to a question on how dissatisfied a graduate was with the match between work and qualifications. The effects of overeducation on earnings and job satisfaction are similar in the three cases, although each measure identifies different individuals as being overeducated.

Similar results were obtained by Groot and Maassen van den Brink (2000) by comparing education level, job level of the worker, and worker self-reports in The Netherlands. They find that only a small fraction of workers designated as overeducated by any of these three measures is so counted by all of them. Furthermore, in contrast with the results of Battu et al. (2000), they find that the estimated rates of return to both overeducation and undereducation vary considerably among the three definitions. Thus, the validity and reliability of mismatching measures appears low, and results from such studies should be treated with caution.

Concerning the heterogeneity of individual skills, the key issue is to what extent perceived mismatches represent labour market on the basis of the varying quality of labour within educational levels. This should be viewed in the context of qualified individuals. When educational standards fall, the employer might respond by upgrading entry qualifications to ensure that new entrants have appropriate skills (grade drift). Alternatively, employers may take advantage of a larger pool of qualified applicants by upgrading some traditionally lower-level jobs or recruiting graduates to previously non-graduate jobs (qualifications inflation). ${ }^{7}$

Assuming the heterogeneity of graduates has increased, Chevalier (2000) distinguishes between the two categories of apparently overeducated and genuinely overeducated graduates. ${ }^{8}$ Subsequently, Chevalier (2003) defines

7. Dolton and Silles (2001) suggest that we can capture this effect by using two separate questions on overeducation, which distinguish between qualifications required for entering a job and qualifications required to actually perform the job. In their sample of graduates, only $58 \%$ believed that a degree was necessary to $d o$ the job, while $67 \%$ of them needed a degree to get the job.

8. Borghans and De Grip (2000), by contrast, refer to the occurence of genuine underutilisation of skills when workers are employed in jobs in which they have lower productivity than others with the same educational background. 
overeducated workers who are satisfied with the match between their education and their work as apparently overeducated, whereas those who are dissatisfied are deemed genuinely overeducated. The genuinely overeducated population, in turn, is composed of two groups that differ in ability: clever graduates in upgraded jobs and underachievers in low-skill jobs.

In the case of apparent overeducated population, where mismatch is minor, individuals should receive more initial training than matched workers to offset their inferior quality, whereas in the case of genuine overeducated population, they should receive less initial training, as their superior quality means they learn faster. Chevalier (2003) then proposes an alternative measure of overeducation based on the answer to a job satisfaction question: "how dissatisfied are you with the match between your work and your qualifications?"9 This measure is used to form a dichotomous variable with satisfied workers being classified as apparently overeducated and dissatisfied workers as genuinely overeducated. ${ }^{10}$ Chevalier estimates that two-thirds of overeducated workers only appear to be overeducated. However, this result is dependent on the classification of jobs according to expert opinion, the division of graduates into two types and the interpretation of the job satisfaction question.

\section{The Competence Approach}

The dominant neoclassical approaches focus on the labour market by equalizing work and occupation. The skills needed to perform that occupation must be acquired before an individual is hired. The researcher can associate individuals and jobs in the same nomenclature. Therefore, there exists a binary relationship between the different types of training and the different types of jobs, which is based on the adequacy of the professional skills. This approach is consistent with the observed facts in the case of regulated occupations (professions), but less accurate for describing labour market exchanges more generally.

The common perspective on the labour market in the HCT, job competition and assignment models assumes that a correspondence between a particular training program and the job currently occupied is optimal for both the worker and the employer. A number of authors have interpreted this as a distinctively normative perspective, based on the presumption that official categories define the optimal allocation of individuals among jobs (Béduwé et al., 2005; Bruno, 1998; Carnoy and Levin, 1985; Franchi, 1984; Franchi, 1992; Planas et al., 2000). These authors maintain that an adequationist approach to the labour market presents far from a precise picture of labour market exchange; moreover, the approach is based on an erroneous definition of the labour market optimum. A competence-based interpretation, on the other

9. This is similar to one of the three measures used by Battu et al. (2000).

10. Overeducated graduates generally express lower job satisfaction than graduates who are properly matched. Belfield and Harris (2002) confirm this but were unable to detect any relation between degree quality and job satisfaction. 
hand, permits us to identify optimal exchanges between the employer and the employee where the neoclassical frameworks only perceive inadequacy and underutilisation of resources.

In contrast to the neoclassical perspective, the competence approach defines the labour market as the aggregation of "know-how" sold by individuals to firms, and bought by firms from individual workers. Transition-from-schoolto-work analysis therefore entails the observation of how skills acquired in training systems are marketed. These skills are diversified according to the supply of training. This diversification can be mapped using both a level indicator, which determines the duration of the training cost, and a speciality indicator, which associates the knowledge acquired with a specific field of activity. Jobs too can be identified by observing their level (the social status they procure) and their field of speciality. Jobs are thus described as diverse, and associated with different social statuses and fields of specialities. To analyse the relationship between training and job, and to evaluate the performance of training programs, the competence approach takes into account the diversity of training programs (level and speciality) as well as the diversity of jobs (social category and field of speciality).

Several authors have distanced themselves from the adequationist models, and instead focus on the notion of skills (Kirsh and Werquin, 1995; Dumartin, 1997; Torres and Chirache, 2001; Chardon, 2005). Jobs are considered as sets of skills performed by individuals, who also comprise sets of skills. These authors maintain that each match between these two different sets of skills is unique. The adequacy of such a match cannot be postulated a priori, but is always determined by observing the individual matches between the training received and the job occupied at a given time (table of contingencies). The results thus obtained are mostly typological, and the authors mainly seek to highlight particular correspondences between training programs and jobs through the analysis of statistical links. The variable heterogeneity of these groups in terms of knowledge exchanged is, in some cases, commented after the statistical analysis. However, these works do not lead, for lack of a synthetic indicator on the match quality, to a proper performance's analysis.

In the methodological approach adopted by Béduwé et al. (2005), the type of education obtained is indicated by its level and speciality. While some occupations require rigid qualifications (e.g., professions), for others educational qualifications are relatively unimportant. Hence, it is important whether the distribution of educational qualifications within particular occupations is narrowly or broadly construed. In some occupations, the number of workers may be so small, or the dispersion of actual qualifications so wide, that any measure of central location is likely to be unreliable. As a rule of thumb, Béduwé et al. (2005) limit their analysis to cases where the modal number of education years is shared by at least $60 \%$ of the workers in that occupation.

Béduwé et. al. (2005) argue that each type of training entails a diversity of level and speciality of jobs. To put it differently, depending on the number of posts to be filled, firms typically recruit individuals that have obtained 
different types of training (different levels as well as different specialities). However, training and jobs are not independent variables. Unless some particular matches between training specialities and occupation specialities arise from a matrix crossing them,. Béduwé et al. (2005) find no evidence of a bijective relation between training and occupation: the matrices crossing them are never "diagonal". This implies that there exists no strict causal relation between training and occupation, irrespective of coding conventions.

Matching between the level and speciality of training and the type of occupation according to the a priori official norm is important with regard to jobs that insist on a qualification as a formal condition for hiring (a "licence"). By contrast, in other jobs such normative matching shows relatively weak relevance. This means there does not exist a "common law" in the relation between training and occupation, but instead we find a large diversity of coexisting pairings. Where the classical adequationist approach only distinguishes between match and mismatch, the competence approach recognises different criteria of what can be considered a "performing pairing".

This last finding is crucial and contradicts the adequationists assumptions of the HCT and the job competition model. It also explains why the manpower planning approach is difficult to implement. Béduwé et al. (2005) argue that an individual is not recruited because he has received a certain type of training: instead, the firm recruits him knowing that he has received this type of training among other information. Each type of training generates its own "pattern of distribution" among all occupations, and each occupation in turn has its own pattern of supply with respect to graduates. Supported by the critique of HCT and the job competition model in the SMLM literature, an empirical competence approach can more adequately explain the observed facts compared with the normative representation of the classical frameworks.

\section{Concluding remarks}

A considerable amount of research aims to explain the SMLM phenomenon within a number of different perspectives on the labour market, and to use this phenomenon to explicitly test the validity of each of these diverging theoretical frameworks.

Regarding the three classical theoretical frameworks, we can conclude that the assignment interpretation of the labour market is most consistent with the findings of existing studies. This conclusion is supported by evidence on the relative returns to education, suggesting variable returns to required, surplus and lack of education. Furthermore, the HCT or the job competition models were largely rejected by empirical studies carrying out formal hypothesis tests. Specifically, the absence of controls for informal human capital accumulation and worker heterogeneity are likely to overstate the effects of overeducation and understate the role of individual's itineraries.

The available data shows that people who have been trained in different specialities are sometimes hired in the same job. Particularly, the non- 
correspondence between level or speciality of training and level or speciality of occupation concerning the labour market insertion of youngsters is largely interpreted as a "failure" associated with underoccupation and overeducation. This interpretation is consistent with a theoretical and methodological approach based on the statement of a previously built norm, rather than an empirical analysis of the various modalities of observed pairings in the labour market. Thus, the analysis based on the normative adequacy between training and employment specialities assumes that the worker's performance depends on such an adequacy.

Nevertheless, a large share of the literature suggest "inadequacy" is hardly the exception in the labour market, and that it will likely increase in the future. The competence approach places the observed no-causality relationship between training and occupation at the centre of this analysis, rather than considering it as a result of market imperfection. Accordingly, this approach provides an alternative way of conceptualising skills mismatch and promisingly challenges the normative assumptions and current applications of the classical frameworks.

\section{Acronyms}

HCT: Human Capital Theory

JA: Job Analysis

MRA: Manpower Requirements Approach

RM: Realized Matches

RoR: Rate of Return

SMLM: Skills Mismatch in the Labour Market

WA: Worker Self-assessment

\section{Bibliographic references}

Ahamad, B. and Blaug, M. (eds.) (1973). The Practice of Manpower Forecasting: A Collection of Case Studies. Amsterdam: Elsevier.

Alba-Ramirez, A. (1993). "Mismatch in the Spanish Labor Market: Overeducation?". Journal of Human Resources, 27 (2), 259-278.

Allen, J. and van der Velden, R. (2001). "Educational Mismatches Versus Skill Mismatches: Effects on Wages, Job Satisfaction and On-the-Job Search". Oxford Economic Papers, 53 (3), 434-452.

Alpin, C.; Shackleton, J. and Walsh, S. (1998). "Over- and Undereducation in the UK Graduate Labour Market”. Studies in Higher Education, 1 (23), 17-34.

Battu, H. and Sloane, P.J. (2002). "To What Extent are Ethnic Minorities in Britain Over-educated?”. International Journal of Manpower, 23 (3), 192-208.

Battu, H. and Sloane, P.J. (2000). "Over-education and Crowding Out in Britain". In: BORGHANS, L. and DE GRIP, A. (eds.), The Overeducated Worker?:Edward Elgar, 157-174.

Battu, H.; Belfield, C.R. and Sloane, P. (2000). "How Well Can We Measure Graduate Over- Education and Its Effects?”. National Institute Economic Review, $171(1), 82-93$. 
Battu, H.; Belfield, C.R. and Sloane, P. (1999). "Overeducation Among Graduates: A Cohort View". Education Economics, 7 (1), 21-38.

Bauer, T. (2002), "Educational Mismatch and Wages: A Panel Analysis", Economics of Education Review, 21 (3), 221-229.

BeCKer, G. (1964). Human Capital: A Theoretical and Empirical Analysis with Special Reference to Education. New York: Columbia University Press.

BÉduWÉ, C.; EsPinASSE, J.E. and VinCENS, J. (2005). "Spécialité de formation, spécialité d'emploi et performance d'insertion”. Discussion Paper, XII Journées d'étude sur les donées longitudinales, Toulouse: Lirhe.

BÉDuwé, C. and Planas, J. (2003). Educational Expansion and Labour Market$E D E X$. Luxembourg: Office for Official Publications of the European Communities.

Belfield, C.R. and Harris, R.D.F. (2000). "How Well Do Theories of Job Matching Explain Variations in Job Satisfaction Across Education Levels? Evidence for UK Graduates". Applied Economics, 34 (5), 535-448.

BERTON F., (2005). "L'articulation formation-emploi dans la valorisation salariale des compétences : l'apport des analyses longitudinales", In: GIRET, J-F; GRELET, Y; Ourtau, M. AND Werquin, P. (eds.), Construction et valorisation des compétences, Actes des 12èmes journées d'étude sur les données longitudinales dans l'analyse du marché du travail, Toulouse May 26-27, CEREQ, Relief. 8, April.

Blaug, M. (1970). Economics of Education. Harmondsworth: Penguin.

Borghans, L. and DE GriP, A. (2000). "Skills and Low Pay: Upgrading or Overeducation?”. In: Gregory, M.; SAlverda, W. and BAZEN, S. (eds.), Labour Market Inequalities. New York: Oxford University Press, 198-224.

Bruno, S. (1998). "The Missing Gene: The Quality Factor”. Vocational Training, 13, 9-11.

BÜChel, F. and BATTU, H. (2003). "The Theory of Differential Overqualification: Does It Work?". Scottish Journal of Political Economy, 50 (1), 1-16.

BÜChel, F. and MerTens, A. (2000). Overeducation, Undereducation and the Theory of Career Mobility. Max Planck Institute of Human Development.

Büchel, F. and Pollmann-Schult, M. (2001). "Overeducation and Human Capital Endowments - The Role of School Achievement and Vocational Training Quality”. IZA Discussion Paper No. 337. Bonn: IZA, 1-29.

BÜCHEL, F. and VAN HAM, M. (2002). "Overeducation, Regional Labour Markets and Spatial Flexibility”. IZA Discussion Paper No. 424. Bonn: IZA, 1-13.

Cain, P. S. and Treiman, D. J. (1981). "The Dictionary of Occupational Titles as a Source of Occupational Data”. American Sociological Review, 46 (3), 253-278.

Carnoy M. and Levin, H. (1985). Schooling and Work in the Democratic State. Palo Alto, CA: Stanford University Press.

Chevalier, A. (2000). "Graduate Over-Education in the UK". CEE Discussion Paper 07 (November). Centre for the Economics of Education: London: 1-21.

Chevalier, A. (2003). ”Measuring Overeducation". Economica, 70, 509-531.

CoHn, E. and KHAN, P. (1995). "The Wage Effects of Overschooling Revisited". Labour Economics, 2 (1), 67-76.

DekKer, R.; DE Grip, A., and HeijKe, H. (2002). "The Effects of Training and Overeducation on Career Mobility in a Sequential Labour Market”. International Journal of Manpower, 23 (2), 106-136.

Dolton, P. and Silles, M. (2001). "Over-education in the Graduate Labour Market: Some Evidence from Alumni Data”. CEE Discussion Paper 09 (June). 
Dolton, P. and Vignoles, A. (2000). "The Incidence and Effects of Overeducation in the U.K. Graduate Labour Market”. Economics of Education Review, 19, 179-198.

DOUGHERTY (1985). "Manpower Forecasting and Manpower-development Planning in the United Kingdom". In: Youdi, R.V. And Hinchliffe, K. (eds.), Forecasting Skilled Manpower Needs: The Experience of Eleven Countries. Comedi, Belgium: UNESCO, 75-98.

Dumartin, S. (1997). “Formation emploi: quelle adéquation?”. Économie et Statistique, 303 59-80.

Duncan, G.J. and Hoffman, S.D. (1981). "The Incidence and Wage Effects of Overeducation". Economics of Education Review, 11 (1), 57-86.

Forgeout, G. and Gautie, J. (1997). "Overeducation in the Youth Labour Market in France". AEA Conference, Maastricht.

FrANCHI, G. (1984). L'istruzione come sistema. Milano: Franco Angeli Ed.

FRANCHI, G. (1992). Istruzione e soggetti sociali. Firenze: La Nuova Italia Editrice.

Frank, R. H. (1978). "Why Women Earn Less: The Theory and Estimation of Differential Overqualification". American Economic Review, 68 (3), 360-373.

Freeman, R. B. (1976). The Overeducated American. New York: Academic Press.

Frenette, M. (2004). "The Overqualified Canadian Graduate: The Role of the Academic Programme in the Incidence, Persistence and Economic Returns to Overeducation". Economics of Education Review, 23, 29-45.

GlebbeeK, A. C. (1993). Perspectieven op Loopbanen. Assen: Van Gorcum.

Green, F.; McIntosh, S. and Vignoles, A. (1999). "Overeducation and Skills Clarifying the Concepts”. CEP Discussion Paper 435. Centre for Economic Performance, London.

Green, F.; McIntosh, S. and Vignoles, A. (2002). "The Utilization of Education and Skills: Evidence from Great Britain”. The Manchester School, 70 (6), 792-811.

Groeneveld, S. and Hartog, J. (2004). "Overeducation, Wages and Promotions within the Firm”. Labour Economics, 11 (6), 701-714.

Groot, W. (1996). "The Incidence and Returns to Overeducation in the UK”. Applied Economics, 28, 1345-1350.

Groot, W. (1993). "Overeducation and the Returns to Enterprise-related Schooling". Economics of Education Review, 17 (4), 299-309.

Groot, W. and MaAsSEn VAn DEN BrinK, H. (2000). "Overeducation in the Labor Market: A Meta Analysis”. Economics of Education Review, 19 (2), 149-158.

Groot, W. and MAassen VAn DEN BrinK, H. (1997). "Allocation and the Returns to Overeducation in the UK”. Education Economics, 50 (2), 169-183.

Hartog, J. (2000), "Overeducation and Earnings: Where We Are, Where We Should Go?”. Economics of Education Review, 19 (2), 185-194.

Hartog, J. (2001), "On Human Capital and Individual Capabilities". Review of Income and Wealth, 47 (4), 515-540.

Hartog, J. and Oosterbeek, H. (1998), "Health, Wealth and Happiness: Why Pursue a Higher Education?”. Economics of Education Review, 17 (3), 245-256.

Heckman, J.; Lochner, J. and Todd, P. (2003). "Fifty Years of Mincer Regressions". IZA Discussion Paper No. 775. Bonn: IZA, 1-52.

Hopkins, J. (2002). Labour Market Planning Revisited. Basingstoke: Palgrave McMillan. ILO (1984). Employment Planning. Santiago: PREALC.

Kiker, B.; Santos, M. and Mendes de Oliveiria, M. (1997). "Overeducation and Undereducation: Evidence for Portugal”. Economics of Education Review, 16 (2), 111-125. 
KirSh, J.L. and Werquin, P. (1995). "Quelque part ... une relation formation emploi”. Formation Emploi, 52, 29-47.

Mason, G. (1996). "Graduate Utilisation in British Industry: The Initial Impact of Mass Higher Education”. National Institute Economic Review, 156, 93-103.

Mason, W. (1979). Guidelines for the Development of Employment and Manpower Information Programmes in Developing Countries: A Practical Guide. Geneva: International Labour Organisation.

McGoldrick, K. and Robst, J. (1996). "Gender Differences in Overeducation: A Test of the Theory of Differential Overqualification". American Economic Review AEA Conference proceedings.

MCGuinness, S. (2006). "Overeducation in the Labour Market". Journal of Economic Surveys, 20 (3), 387-418.

McGuinness, S. (2003). "Graduate Overeducation as a Sheepskin Effect: Evidence from Northern Ireland”. Applied Economics, 35 (5), 597-608.

McGuinness, S. and BenNeT, J. (2006). "Overeducation in the Graduate Labour Market: A Quantile Regression Approach”. Economics of Education Review, 22 (1), 65-82.

McMillen, D.P.; Seaman, P.T. and Singell, L.D. (1999). "A Hedonic Analysis of Overeducation and Undereducation”. University of Oregon Working Papers, University of Oregon.

Mendes De Oliveria, M.; Santos, M.C. and Kiker, B. (2000). "The Role of Human Capital and Technological Change in Overeducation". Economics of Education Review, 19 (2), 199-206.

Middleton, J.; Ziderman, A. and Van Adams, A. (1993). Skills for ProductivityVocational Education and Training in Developing Countries. New York: Oxford University Press and World Bank.

Mincer, J. (1974). Schooling, Experience and Earnings. New York: Columbia University Press.

Planas, J.; Giret, J.F.; Sala, G. and Vincens, J. (2000). "Skills Market: Dynamics and Regulation". In: Descy, P. and TEssaring, M. (eds.), Vocational Training in Europe. Second Report on Vocational Training Research in Europe. Cedefop Reference series. Luxembourg: Office for Official Publications of the European Communities, Vol. II.

Psacharopoulos, G. (1991). "From Manpower Planning to Labour Market Analysis". International Labour Review, 130 (4), 459-474.

RENES, G. and RidDER, G. (1995). “Are Women Overqualified?”. Labour Economics, 2 (1), 3-18.

RichteR, L. (1989). Upgrading Labour Market Information in Developing Countries: Problems, Progress and Prospects. Geneva: International Labour Organisation.

RiCHTER, L. (1982), "Manpower and Employment Information Through Key Informants". International Labour Review, 121 (4), 417-33.

Robst, J. (1995). “Career Mobility, Job Match, and Overeducation”. Eastern Economic Journal, 2 (4), 539-550.

Rumberger, R. (1987), “The Impact of Surplus Education on Productivity and Earnings". Journal of Human Resources, 22 (1), 24-50.

SATTINGER, M. (1993). "Assignment Models of the Distribution of Earnings". Journal of Economic Literature, 31 (2), 831-880.

Sicherman, N. (1991). "Overeducation in the Labor Market". Journal of Labor Economics, 9 (2), 101-122. 
Sicherman, N. and Galor, O. (1990). "A Theory of Career Mobility". Journal of Political Economy, 98 (1), 169-192.

Sloane, P.; Battu, H. and Seaman, P. (1999). "Overeducation, Undereducation and the British Labour Market”. Applied Economics, 31 (11), 1437-1453.

Sloane, P.J. (2003). "Much Ado About Nothing? What Does the Overeducation Literature Really Tell Us?”. In: BÜCHEL, F; DE GrIP, A. and Mertens, A. (eds.), Overeducation in Europe. Cheltenham: Edward Elgar, 11-45.

Spence, M. (1973). "Job Market Signalling”. Quarterly Journal of Economics, 87 (3), 355-374.

Thurow, L.C. (1975). Generating Inequality. New York: Basic Books.

Torres, D. and Chirache, S. (2001). "Analyse des liens formation-emploi chez les jeunes débutants". Note d'information No. 01.60. Ministère de l'Éducation Nationale (DEP), 1-5.

TSANG, M. (1987). "The Impact of Underutilisation of Education of Productivity: A Case Study of the U.S. Bell Companies". Economics of Education Review, 11, 239-234.

Tsang, M.; Rumberger, R. and Levin, H. (1991). "The Impact of Surplus Schooling on Worker Productivity”. Industrial Relations, 30 (2), 209-228.

Vahey, S., (2000). "The Great Canadian Training Robbery: Evidence on the Returns to Educational Mismatch". Economics of Education Review, 19 (2), 219-227.

VAN DER Velden, R.K.W. and VAN SMOOREnburG, M.S.M. (1997). "The Measurement of Overeducation and Undereducation: Self-report Versus the Job-analyst Method". University of Maastricht. Mimeo.

Verdugo, R., and Verdugo, N. (1992). "Surplus Schooling and Earnings: Reply to Cohn and to Gill and Sollberg". Journal of Human Resources, 22 (4), 690-695.

Verdugo, R. and Verdugo, N. (1989). "The Impact of Surplus Schooling on Earnings". Journal of Human Resources, 24 (4), 629-643.

Youdi, R.V. and HinCHLiffe, K. (eds.) (1985). Forecasting Skilled Manpower Needs: The Experience of Eleven Countries. Comedi, Belgium: UNESCO. 


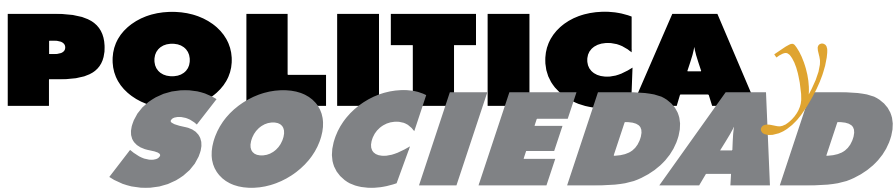

Revista cuatrimestral de Ciencias Sociales

Facultad de Ciencias Políticas y Sociología. Universidad Complutense de Madrid

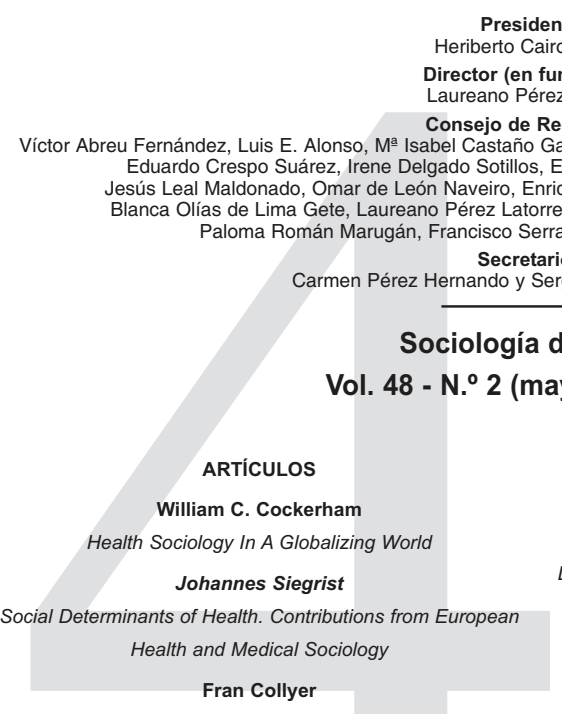

The Sociology of Health and Medicine in Australia

Juan Irigoyen

La reestructuración de la profesión médica

Roberto Castro

Sociología de la salud en México

Madel Therezinha Luz

El desafío de la salud en las ciencias sociales:

$$
\text { el caso de Brasil }
$$

Manuel Espinel, Marcial Romero, Lorenzo Fernández, Juan Torres y Sergio D'Antonio

Utilización por cuenta propia de los Servicios de Urgencias Hospitalarias: razones que dan las personas con problemas de salud de baja complejidad para utilizar estos servicios

Presidente

Cairo Carou

(en funciones)

Consejo de Redacción

Juan José Castillo Alonso, María Cátedra Tomás,

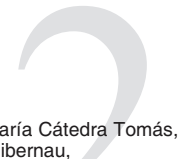

Be Baena, Lorenzo Navarrete Moreno,

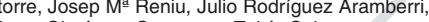

do y Sergio D' Antonio Maceiras 